\title{
PENGARUH JUMLAH KELAS DAN SKEMA KLASIFIKASI TERHADAP AKURASI INFORMASI PENGGUNAAN LAHAN HASIL KLASIFIKASI BERBASIS OBJEK DENGAN TEKNIK SUPPORT VECTOR MACHINE DI SEBAGIAN KABUPATEN KEBUMEN PROVINSI JAWA TENGAH
}

\author{
Aria Jaka Dwiputra ${ }^{1}$, R. Suharyadi ${ }^{2}$, dan Projo Danoedoro
}

Kementrian Agraria dan Tata Ruang, Badan Pertanahan Nasional, Fakultas Geografi, Universitas Gadjah Mada, Yogyakarta, Indonesia $a^{2,3}$

dwiputraariajaka@gmail.com

Diterima : Desember 2015; Direvisi : Juni 2016.; Dipubikasikan: September 2016

\begin{abstract}
ABSTRAK Produksi peta penggunaan lahan dari data geospasial satelit harus memperhatikan resolusi spasial yang digunakan, dengan menggunakan ilmu penginderaan jauh secara digital akurasi informasi geospasial tematik yang diperoleh dari data geospasial satelit dapat diukur secara kuantitatif. Jumlah kelas penggunaan lahan, skema klasifikasi, dan teknik ekstraksi informasi akan berpengaruh dalam overall accuracy.Penelitian ini menggunakan tiga variasi jumlah kelas dan skema klasifikasi yaitu 4, 7, dan 10 kelas penggunaan lahan. Tiga variasi tersebut diekstraksi dari citra ALOS AVNIR - 2 dengan resolusi 10 meter menggunakan metode klasifikasi berbasis objek dengan pendekatan support vector machine. Sesuatu yang lain dari klasifikasi berbasis objek adalah proses segmentasi yang mengelompokkan objek tutupan lahan dalam satu bagian, dan algoritma SVM mengklasifikasikan citra segmentasi dengan memanfaatkan empat tipe kernel yaitu linier, radial basis function, sigmoid, dan polynomial. Hasil ekstraksi informasi penggunaan lahan untuk jumlah kelas empat menggunakan klasifikasi berbasis objek dengan pendekatan support vector machine memiliki akurasi sebesar $87.2666 \%$ serta nilai koefesien kappa 0.8048 dan tipe kernel yang dipakai adalah kernel Linier. Hasil ekstraksi informasi penggunaan lahan untuk jumlah kelas tujuh menggunakan klasifikasi berbasis objek dengan pendekatan support vector machine memiliki akurasi sebesar $79.8021 \%$ serta nilai koefesien kappa 0.7293 dan tipe kernel yang dipakai adalah kernel Linier. Hasil ekstraksi informasi penggunaan lahan untuk jumlah kelas sepuluh menggunakan klasifikasi berbasis objek dengan pendekatan support vector machine memiliki akurasi sebesar $73.3377 \%$ serta nilai koefesien kappa 0.6466 dan tipe kernel yang dipakai adalah kernel Linier. Hasil ekstraksi informasi penggunaan lahan untuk jumlah kelas sepuluh menggunakan klasifikasi berbasis objek dengan pendekatan support vector machine dan ditambah dengan data bantu berupa informasi lereng dan informasi pola ruang memiliki akurasi sebesar 77.5705\% serta nilai koefesien kappa 0.6982 dan tipe kernel yang dipakai adalah kernel Radial Basis Function. Kernel linier dengan satu parameter menunjukkan akurasi tertinggi pada setiap jumlah kelas yang berbeda. Kernel linier menunjukkkan akurasi terendah ketika dipakai data bantu dalam proses klasifikasi. Berdasarkan hasil penelitian didapat bahwa dengan semakin banyaknya parameter yang dipakai dalam proses klasifikasi tidak berarti semakin akurat hasil klasifikasinya. Setiap kernel memiliki pengaruh spesifik terhadap objek penggunaan lahan, dan untuk meningkatkan akurasi per objek penggunaan lahan dapat menggunakan data bantu.
\end{abstract}

Kata kunci: jumlah kelas; klasifikasi berbasis objek; kernel; penggunaan lahan; skema klasifikasi; SVM

\begin{abstract}
The production of land use maps from geospatial data satellite have to consider the spatial resolution within, with digital remote sensing science geospatial thematic information accuracy that extracted from geospatial satellite data can be measured quantitatively. Class number, classification schemes, and method in extraction information will affect the overall accuracy. This research used three variations of class number and classification schemes, namely 4, 7, and 10. Three variations simulation were extracted from ALOS AVNIR - 2 with a resolution of 10 meters using an object-based classification method with support vector machine approach. What makes difference from object-based classification is the process of classifying land cover information through objects segmentation into one section, and the SVM algorithm classifies the image segmentation using four types of kernels such as linear, radial basis function, sigmoid, and polynomial. The results of Land use information extraction for four number of classes using an object-based classification with support vector machine approach has an accuracy of 87.2666\% and kappa coefficient 0.8048 and the kernel type that used is a linear kernel. The results of Land use information extraction for seven number of classes using an object-based classification with support vector machine approach has an accuracy of 79.8021\% and kappa coefficient 0.7293 and the kernel type that used is a linear kernel. The result of Land use information extraction for ten number of classes using an objectbased classification with support vector machine approach has an accuracy of 73.3377\% and kappa coefficient 0.6466 and the kernel type that used is a linear kernel. The result of land use information extraction for ten number of classes using the object-based classification with support vector machine approach and added with additional data in the form of slopes and spatial patterns have an accuracy of 77.5705\% and coefficient kappa 0.6982 and the kernel type that used is the kernel Radial Basis Function. Linear kernel with one parameter indicates the highest accuracy in any number of different classes. Kernel linear indicating low accuracy when additional data used in the process. Based on the research result we know that a growing number of parameters that used in the process does not mean the results will be more accurate. Each kernel has a specific effect on the land use objects, and to improve the accuracy of land use object we can use additional data.
\end{abstract}

Key words: number of classes; object-based image classification; kernel; land use; classification scheme; SVM 


\section{PENDAHULUAN}

Berdasarkan Undang - Undang Republik Indonesia No. 4 Tahun 2011, informasi geospasial merupakan data geospasial yang telah diolah. Data geospasial adalah data tentang lokasi geografis, dimensi atau ukuran, dan/atau karakteristik objek alam dan/atau buatan manusia yang berada di bawah, pada, atau di atas permukaan bumi. Informasi geospasial terbagi menjadi dua yaitu informasi geospasial dasar, dan informasi geospasial tematik. Peta rupa bumi indonesia yang dibuat oleh Badan Informasi Geospasial (BIG) adalah salah satu bentuk informasi geospasial dasar, sedangkan peta penggunaan lahan yang dibuat oleh Badan Pertanahan Nasional Republik Indonesia (BPN RI) merupakan salah satu contoh dari informasi geospasial tematik. Informasi penggunaan lahan merupakan informasi geospasial tematik yang memiliki peranan penting dalam perencanaan dan pembangunan suatu wilayah. Informasi penggunaan lahan berguna untuk memberikan informasi mengenai potensi suatu wilayah yang dapat digunakan untuk mengetahui perencanaan pengembangan wilayah, mendukung pengambilan keputusan dalam perencanaan dan pengelolaan penggunaan lahan, sumber daya alam, lingkungan, transportasi, fasilitas kota-desa, dan pelayanan umum lainnya.

Saat ini BPN RI telah memanfaatkan data geospasial satelit sebagai salah satu sumber informasi geospasial tematik penggunaan lahan, namun pengolahan data geospasial dengan cara otomatis digital masih sangat sedikit digunakan. Produksi peta penggunaan lahan masih dilaksanakan dengan cara terrestrial manual dan dengan memanfaatkan sistem informasi geografis, data spasial satelit digunakan sebagai data bantu dalam pembuatan peta kerja lapangan. Dalam produksi peta kerja lapangan, pengolahan data geospasial satelit dilakukan dengan cara manual atau visual dengan memanfaatkan data geospasial satelit tercetak untuk kemudian dianalisis secara manual atau visual dengan sistem informasi geografis, sedangkan pengolahan berbasis ilmu penginderaan jauh dengan interpretasi digital otomatis dengan bantuan komputer sangat sedikit diterapkan.

Penginderaan jauh adalah ilmu dan seni untuk memperoleh informasi tentang suatu objek, daerah atau fenomena melalui analisis data yang diperoleh dengan suatu alat tanpa kontak langsung dengan objek, daerah atau fenomena yang dikaji (Lillesand dan Kiefer, 2007). Penerapan ilmu penginderaan jauh dalam metode pembuatan peta penggunaan lahan dapat meningkatkan efektivitas field check dan efesiensi waktu dan biaya dibandingkan dengan menggunakan metode terestris manual. Salah satu cara memperoleh informasi penggunaan lahan adalah dengan menggunakan data geospasial dari satelit (Menno dan Ferjan, 2007). ALOS AVNIR - 2 merupakan data geospasial dengan resolusi spasial sebesar 10 meter, dan memiliki 4 saluran spekral yaitu gelombang biru, gelombang hijau, gelombang merah, dan gelombang inframerah. Dengan karakteristik tersebut, ALOS AVNIR-2 dapat dikategorikan sebagai data geospasial satelit resolusi menengah, dimana data geospasial satelit resolusi menengah merupakan data geospasial satelit dengan resolusi 5 - 60 meter (Lillesand dan Kiefer, 2007).

Peta penggunaan lahan yang diselenggarakan oleh BPN RI diproduksi pada skala 1:100.000, 1:50.000, 1:25.000, dan 1:10.000. Dalam pembuatan peta penggunaan lahan berdasarkan peraturan dan perundangan dilarang menggunakan skala/resolusi yang lebih besar dari data geospasial yang digunakan, hal ini untuk menjamin keakuratan informasi geospasial dasar dan tematik yang diperoleh. Penggunaan data spasial dari satelit harus sesuai dengan asas keakuratan, yaitu bahwa penyelenggaraan informasi geospasial harus diupayakan untuk menghasilkan informasi geospasial yang teliti, tepat, benar, dan berkualitas sesuai dengan kebutuhan. Penggunaan data geospasial satelit harus disesuaikan dengan skala kebutuhan informasi yang diperlukan oleh pengguna, dengan memperhatikan asas keakuratan. Penggunaan data geospasial satelit dengan resolusi spasial 100 meter tidak dapat digunakan untuk pembuatan peta penggunaan lahan dengan skala 1:50.000.

Produksi peta penggunaan lahan dari data geospasial satelit harus memperhatikan resolusi spasial yang digunakan, dengan menggunakan ilmu penginderaan jauh secara digital akurasi informasi geospasial tematik yang diperoleh dari data geospasial satelit dapat diukur secara kuantitatif. Akurasi merupakan hal yang penting dalam ekstraksi informasi geospasial tematik dari data geospasial satelit, jika akurasi yang diperoleh tidak baik maka manfaat yang dihasilkan tidak akan maksimal. Akurasi hasil analisis data geospasial dapat dievaluasi dari dua aspek yaitu aspek kedalaman isi dan aspek kebenaran di lapangan. Aspek kedalaman isi berkaitan dengan tingkat kerincian informasi secara tematik (Anderson et al. 2001), sedangkan aspek kebenaran klasifikasi di lapangan berkaitan dengan tepat tidaknya informasi geospasial tematik pada suatu posisi koordinat tertentu.

Aspek kedalaman isi sangat erat kaitannya dengan skema klasifikasi yang digunakan dalam ekstraksi informasi tematik dari data geospasial satelit. Beberapa 
skema klasifikasi lahan yang digunakan di Indonesia antara lain adalah sistem klasifikasi I Made Sandy (1977), sistem klasifikasi Malingreau dan Christian (1981), sistem skema klasifikasi Danoedoro (2006), dan sistem klasifikasi Badan Pertanahan Nasional Republik Indonesia (BPN RI). BPN RI mempunyai skema klasifikasi penggunaan lahan yang digunakan sebagai dasar dalam penentuan kelas dalam peta penggunaan lahan, skema tersebut mengacu kepada sistem klasifikasi I Made Sandy (1977) dan dibagi kedalam beberapa skala kelas penggunaan lahan dimana semakin besar skala semakin detil informasi penggunaan lahannya. Namun skema klasifikasi BPN RI dibuat berbasis pada survei terrestrial manual dan belum ada secara teknis pemisahan kelas tutupan dan penggunaan lahan. Sistem klasifikasi Malingreau dan Christian (1981), merupakan sistem klasifikasi tutupan lahan berjenjang berdasarkan kriteria physiognomic, floristic, ekologi, dinamika dan fungsi, serta geografinya. Basis data geospasial yang digunakan adalah data geospasial satelit. Skema klasifikasi Danoedoro (2006) merupakan skema klasifikasi yang berbasis data geospasial satelit yang bersifat multidimensi dan multilevel. Penentuan skema klasifikasi akan sangat berpengaruh terhadap jumlah kelas yang dapat diperoleh dari data geospasialselain ituharus sesuai dengan basis data geospasial yang digunakan dan juga metode ekstraksi yang digunakan untuk memperoleh akurasi minimal $>85 \%$ dalam ekstraksi informasi geospasial tematik yang dibutuhkan.

Jumlah kelas yang dapat diperoleh dari data geospasial satelit dengan resolusi tinggi akan sangat bervariasi dibandingkan dengan penggunaan data geospasial satelit resolusi rendah. Dengan menggunakan data geospasial satelit resolusi tinggi jumlah kelas klasifikasi dapat disesuaikan dengan tingkat skema yang berbeda, sebagai contoh data geospasial satelit dengan resolusi 5 meter dapat dipakai untuk membuat peta penggunaan lahan > 1:5.000, namun data geospasial satelit dengan resolusi 30 meter tidak dapat dipakai untuk membuat peta penggunaan lahan < 1:50.000. Jumlah kelas klasifikasi yang dapat diekstrak dari data geospasial satelit sangat dipengaruhi oleh metode klasifikasi digital penginderaan jauh yang digunakan. Metode klasifikasi digital penginderaan jauh dapat dibagi menjadi dua (1) klasifikasi berbasis piksel, (2) klasifikasi berbasis objek. Penerapan kedua klasifikasi tersebut memiliki beberapa macam variasi, dibagi berdasarkan pendekatan yang digunakan dalam klasifikasi seperti algoritma, otomatisasi, dan lain lain.
Klasifikasi berbasis piksel bertujuan untuk menghasilkan informasi baru berdasarkan karakteristik spektralnya. Secara konseptual informasi baru dihasilkan dengan cara mengkategorikan piksel piksel pada data geospasial satelit menjadi kelas - kelas tematik (tutupan lahan, kerapatan vegetasi, dll). Setiap kenampakan pada citra memiliki nilai piksel yang berbeda berdasarkan pada pola tanggap spektralnya. Pengenalan terhadap pola tanggap spektral berkenaan dengan metode klasifikasi yang menggunakan nilai piksel sebagai dasar klasifikasi tutupan lahan (Lillesand dan Kiefer, 2007). Akurasi hasil klasifikasi berbasis piksel terhadap data geospasial dengan berbagai macam resolusi spasial sangat tergantung pada algoritma klasifikasi yang digunakan, salah satu algoritma yang sering digunakan adalah support vector machine (SVM).

SVM merupakan klasifikasi berbasis piksel pembelajaran terarah (supervised learning), dan dikenal sebagai teknik pembelajaran mesin (machine learning) paling mutakhir setelah pembelajaran mesin sebelumnya yang dikenal sebagai Neural Network $(\mathrm{NN})$. Para peneliti internasional dalam bidang penginderaan jauh telah banyak meneliti SVM sebagai klasifikasi berbasis piksel, dengan menggunakan berbagai macam resolusi data geospasial satelit dan skema klasifikasi yang beragam. Bahkan perbandingan penelitian antara SVM dengan metode klasifikasi lain, seperti $K$ Nearest Neighbor, Maximum Likelihood, Decision Tree, dan Neural Network menunjukkan bahwa akurasi dari SVM sangat memuaskan dan di atas akurasi metode klasifikasi lain (Huang et al., 2002; Foody dan Mather, 2004).

Perkembangan resolusi data geospasial satelit, berakibat kepada berkembangnya metode ekstraksi informasi geospasial tematik yang berbeda dengan klasifikasiberbasis piksel, yang biasa diterapkan pada data spasial resolusi menengah dan rendah. Dalam penerapannya klasifikasi berbasis piksel memiliki beberapa kekurangan yaitu piksel bukan obyek geografis (geo-object) dan topologi piksel terbatas, analisis data geospasial satelit berbasis piksel sebagian besar mengabaikan elemen foto - interpretatif spasial seperti tekstur, konteks, dan bentuk, peningkatan variabilitas secara implisit dalam data geospasial satelit resolusi spasial tinggi menyebabkan klasifikasi berbasis piksel menghasilkan akurasi yang lebih rendah ( dan Castilla, 2006). Keterbatasan - keterbatasan dalam klasifikasi berbasis piksel memunculkan beberapa alternatif dalam metode ekstraksi informasi dari data geospasial satelit, salah satunya adalah klasifikasi berbasis objek (object based clasification). 
Wong (2004) menyatakan klasifikasi berbasis objek dipandang mampu mengatasi kelemahan metode klasifikasi yang selama ini beroperasi pada level piksel secara individual. Blaschke dan Strobl (2001) mengajukan adanya klasifikasi dari kelompok piksel yang homogen dengan menggunakan algoritma untuk melakukan delineasi objek berdasarkan informasi kontekstual dari sebuah data spasial dengan menggunakan segmentasi. Segmentasi digunakan untuk membuat "objek" dengan melibatkan informasi ketetanggaan dan memasukkan informasi spasial berupa tekstur, dan ukuran. Pembatasan objek ini secara konseptual meniru interpretasi visual manusia meskipun masih terbatas. Schiewe, (2002) dalam Blaschke (2010) menjelaskan bahwa segmentasi citra dilihat dari perspektif algoritma dapat dibedakan menjadi empat kriteria (a) berbasis titik/piksel, (b) berbasis tepi (edge), (c) berbasis area (region), dan (d) kombinasi. Penggunaan segmentasi dalam klasifikasi berbasis objek merupakan jembatan untuk mengkelaskan objek menjadi tutupan atau penggunaan lahan.

Klasifikasi berbasis objek dalam penerapannya dapat disertakan dalam beberapa metode seperti klasifikasi terselia (supervised clasification), logika samar (fuzzy logic), dan rule-based classification (Shackelford dan Davis, 2003 dalam Gao, 2009). Klasifikasi berbasis objek merupakan klasifikasi yang mendasari ekstraksi otomatis informasi penggunaan lahan berbasis tutupan lahan dari data geospasial satelit, karena hasil segmentasi yang dihasilkan adalah visualisasi dari objek dengan nilai spektral yang homogen yaitu tutupan lahan. Hasil segmentasi dapat langsung diidentifikasi sebagai objek penggunaan lahan.

\section{METODE PENELITIAN}

Penelitian dimulai dengan menyiapkan bahan dan alat penelitian yang akan menunjang proses penelitian. Data geospasial yang akan dipakai adalah Citra ALOS AVNIR-2 sebagian daerah Kabupaten Kebumen dan informasi geospasial dasar yang digunakan adalah Peta Rupa Bumi Indonesia Kebumen (1408-141) skala 1:25.000 (BIG). Penelitian secara garis besar meliputi kajian akurasi informasi penggunaan lahan hasil klasifikasi berbasis objek dengan teknik SVM.

Tujuan pertama adalah untuk mengetahui tingkat akurasi informasi penggunaan lahan hasil klasifikasi berbasis objek dengan teknik SVM menggunakan citra ALOS AVNIR - 2 resolusi 10 meter dengan jumlah kelas dan skema klasifikasi penggunaan lahan yang berbeda. Tujuan kedua adalah untuk mengetahui pengaruh kernel SVM terhadap tingkat akurasi klasifikasi berbasis objek dengan jumlah kelas dan skema klasifikasi yang berbeda berbasis citra ALOS AVNIR - 2 resolusi 10 meter (Gambar 1). Tujuan ketiga adalah untuk mengetahui pengaruh kernel SVM terhadap tingkat akurasi objek penggunaan lahan yang berbeda.

Tahapan penelitian meliputi (a) tahap persiapan yaitu tahap persiapan bahan, alat penelitian dan pemilihan daerah kajian, (b) pengolahan awal citra, (c) penentuan skema klasifikasi penggunaan lahan dan jumlah kelas untuk simulasi penelitian, (d) klasifikasi berbasis objek meliputi segmentasi berbasis tepi (watershed), dan klasifikasi support vector machine (SVM) dengan pendekatan terselia, (e) uji akurasi dengan matriks kesalahan dan analisis Kappa, dan (f) analisis kualitatif informasi yang dihasilkan (Gambar 2).

\section{Pemilihan Skema dan Jumlah Kelas Klasifikasi}

Penelitian ini menggunakan skema klasifikasi multiguna yang dikembangkan oleh Danoedoro (2006) dan skema penggunaan lahan BPN RI. Skema klasifikasi yang digunakan untuk ekstraksi informasi penggunaan lahan adalah skema klasifikasi dimensi sosial ekonomi dan BPN RI dengan penyesuaian untuk ekstraksi informasi penggunaan lahan. Tabel 1 berikut adalah tabel jumlah kelas dan skema klasifikasi penggunaan lahan dengan penyesuaian yang akan digunakan dalam penelitian.

Jumlah kelas dalam penelitian ini dipengaruhi oleh (1) resolusi data geospasial yang digunakan adalah ALOS AVNIR -2 dengan resolusi 10 meter, (2) lokasi penelitian yaitu sebagian Kabupaten Kebumen dengan variasi penggunaan lahan yang cukup beragam dan, (3) skema klasifikasi yang digunakan sebagai rujukan yaitu skema klasifikasi penggunaan lahan multiguna dimensi sosial-ekonomi dan skema klasifikasi penggunaan lahan BPN RI.

1. Jumlah kelas empat didasari oleh skema klasifikasi penggunaan lahan multiguna dimensi sosialekonomi untuk resolusi $>100$ meter;

2. Jumlah kelas tujuh didasari oleh asosiasi antara skema klasifikasi multiguna dimensi sosialekonomi untuk resolusi 30 - 100 meter dan skema klasifikasi penggunaan lahan BPN RI skala 1: 100.000 dikaitkan dengan informasi pra lapangan lokasi penelitian;

3. Jumlah kelas sepuluh didasari oleh asosiasi antara skema klasifikasi multiguna dimensi sosialekonomi untuk resolusi 10 - 30 meter dan skema klasifikasi penggunaan lahan BPN RI skala 1: 50.000 dikaitkan dengan informasi pra lapangan lokasi penelitian. 
4. Penggunaan data bantu dalam penelitian ini akan dipergunakan untuk memberikan batasan detail informasi penggunaan lahan sehingga tingkat akurasi dapat ditingkatkan selain digunakan sebagai pembanding, data bantu yang dipertimbangkan untuk digunakan adalah informasi pola ruang, dan kemiringan lereng.

Tabel 1. Jumlah Kelas dan Skema Penggunaan Lahan dengan Penyesuaian

\begin{tabular}{lcl}
\hline Keterangan & No & Skema Klasifikasi \\
\hline Jumlah Kelas 4 & 1 & Utilitas Berbasis Air \\
2 & Utilitas Berbasis Hutan \\
3 & Penggunaan Pertanian \\
Jumlah Kelas 7 & 1 & Permukiman Dan Infrastruktur \\
& 2 & Sungai \\
3 & Semak Belukar \\
4 & Lahan Padi/Persawahan \\
5 & Permukiman Dan Fungsi Pelengkapnya \\
6 & Transportasi, Komunikasi Dan Utilitasnya \\
7 & Lahan Terbuka Dengan Fungsi Terkait \\
1 & Sungai \\
2 & Saluran Drainase/Irigasi \\
Jumlah Kelas 10 & 3 & Hutan Lebat \\
& 4 & Semak Belukar \\
5 & Sawah Tadah Hujan \\
6 & Sawah Irigasi \\
7 & Perumahan Kota \\
8 & Permukiman Desa \\
9 & Transportasi Dan Utilitasnya \\
10 & Lahan Terbuka Dengan Fungsi Terkait \\
\hline
\end{tabular}

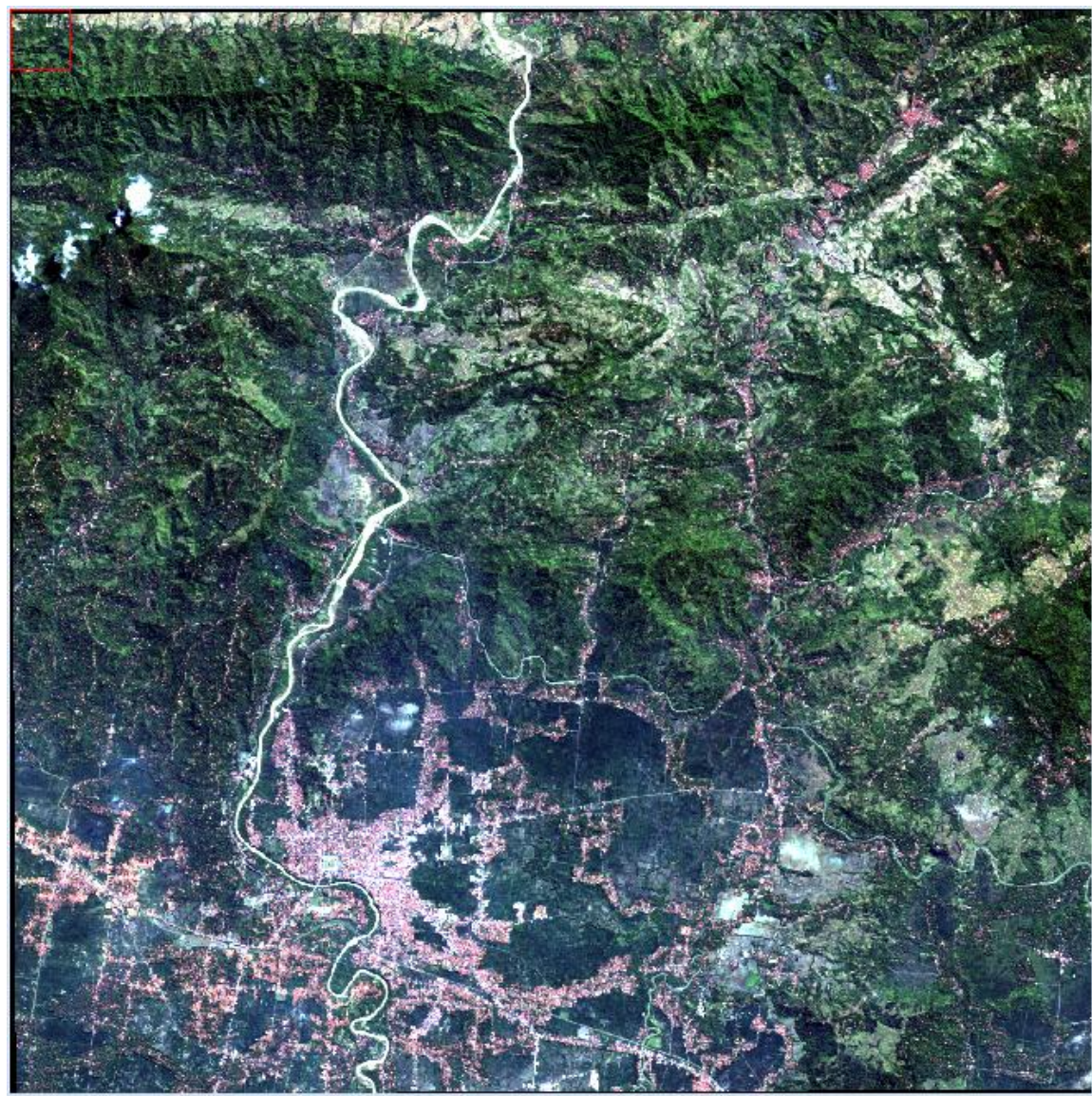

Gambar 1. Lokasi Penelitian, Citra ALOS AVNIR - 2 Komposit 321(1.500x1.500 Piksel) 


\section{HASIL DAN PEMBAHASAN}

Analisis Tingkat Akurasi Hasil Klasifikasi Berbasis Objek Dengan Teknik Support Vector Machine Berbasis Citra ALOS AVNIR - 2

Tingkat akurasi yang dianalisis dalam bagian ini adalah tingkat akurasi terbaik dari klasifikasi berbasis objek dengan teknik support vector machine per skema klasifikasi dan jumlah kelas penggunaan lahan yang di ekstraksi. Ektraksi informasi penggunaan lahan berbasis citra ALOS AVNIR-2 untuk empat kelas adalah 87,27 \% dengan kappa 0,80 (Tabel 2). Hal ini menginformasikan bahwa citra ALOS AVNIR-2 dapat di gunakan untuk ekstraksi informasi penggunaan lahan dengan resolusi spasial di atas 100 meter. Ekstraksi informasi penggunaan lahan dengan jumlah kelas tujuh dan sepuluh memiliki tingkat akurasi di bawah $80 \%$. Ekstraksi di laksanakan dengan menggunakan data spektral citra tanpa menggunakan data bantu berupa data transformasi citra atau pun data nir spektral. Pada simulasi ekstraksi informasi penggunaan lahan dengan jumlah kelas 10, di gunakan data bantu lereng dan pola ruang untuk mendapatkan informasi khusus dari objek penggunaan lahan. Dari simulasi di dapat data bantu dapat menaikkan nilai akurasi dengan baik.

Pengaruh jumlah kelas terhadap akurasi hasil klasifikasi berbasis objek dengan teknik support vector machine adalah berbanding terbalik, yaitu semakin banyak jumlah kelas penggunaan lahan yang diekstraksi maka semakin menurun akurasi yang diperoleh (Gambar 3). Akurasi informasi penggunaan lahan yang di hasilkan dari simulasi memiliki nilai di atas $70 \%$, informasi tersebut dapat di tingkatkan akurasinya dengan menambah jumlah training area, menggunakan data bantu citra transformasi spektral NDVI, NDBI, FCD, atau pun data nir spektral berupa peta kawasan hutan, pemetaan terestris lokal, dll.

Pengaruh Tipe Kernel Terhadap Akurasi Hasil Klasifikasi Berbasis Objek Dengan Teknik Support Vector Machine
Tipe kernel dalam algoritma support vector machine memiliki parameter yang berbeda - beda, penalty parameter, gamma, bias, degree. Kernel linier memiliki satu parameter dalam menentukan kelas klasifikasi yaitu penalty parameter, kernel radial basis function memiliki dua parameter yaitu penalty parameter dan gamma, kernel sigmoid mempunyai tiga parameter yaitu penalty parameter, gamma, dan bias, sedangkan kernel polynomial memiliki empat parameter yaitu penalty parameter, gamma, bias, dan degree.

Berdasarkan hasil penelitian didapat bahwa dengan semakin banyaknya parameter yang dipakai dalam proses klasifikasi tidak berarti semakin akurat hasil klasifikasinya. Kernel linier dengan satu parameter menunjukkan akurasi tertinggi pada setiap jumlah kelas yang berbeda. Kernel linier menunjukkkan akurasi terendah ketika dipakai data bantu dalam proses klasifikasi (Tabel 3).

Tingkat akurasi untuk setiap jumlah kelas menurun untuk kernel linier, sigmoid, RBF dan polinomial dalam algoritma support vector machine, namun untuk kernel RBF pada kelas 10 jika ditambah data bantu berupa lereng dan pola ruang maka tingkat akurasi menjadi $77.5705 \%$ lebih baik dibandingkan dengan tingkat akurasi pada kelas 7 yaitu $75.1375 \%$. Berikut adalah tabel (Tabel 4) dan diagram dari hubungan antara jumlah kelas dengan tingkat akurasi dikaitkan dengan tipe kernel dalam algoritma support vector machine klasifikasi berbasis objek (Gambar 4, 5, 6, 7 dan 8)

Tabel 2. Nilai Uji Akurasi Dari Jumlah Kelas per OBIA Algoritma SVM

\begin{tabular}{|c|c|c|c|}
\hline \multirow[b]{2}{*}{ Keterangan } & & \multicolumn{2}{|c|}{ OBIA SVM } \\
\hline & & Overall & Kappa \\
\hline & & & \\
\hline Jumlah Kelas & 4 & $87.27 \%$ & 0.8048 \\
\hline \multirow[t]{3}{*}{ Penggunaan Lahan } & 7 & $79.80 \%$ & 0.7293 \\
\hline & 10 & $73.34 \%$ & 0.6466 \\
\hline & $10+$ & $77.57 \%$ & 0.6982 \\
\hline
\end{tabular}

Sumber : Hasil Pengolahan

Diagram Pengaruh Jumlah Kelas Terhadap Tingkat Akurasi

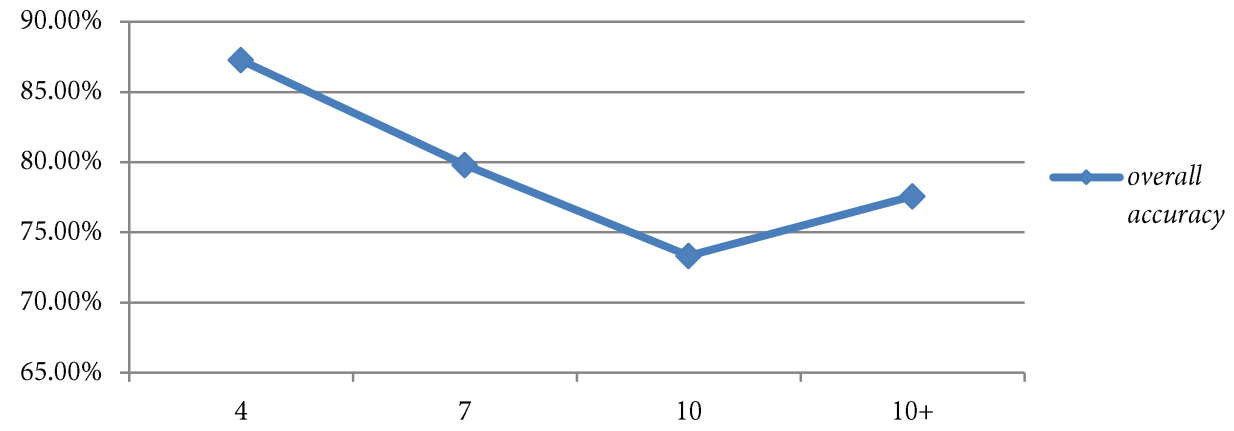

Gambar 3. Diagram Pengaruh Jumlah Kelas terhadap Tingkat Akurasi per Kelas 


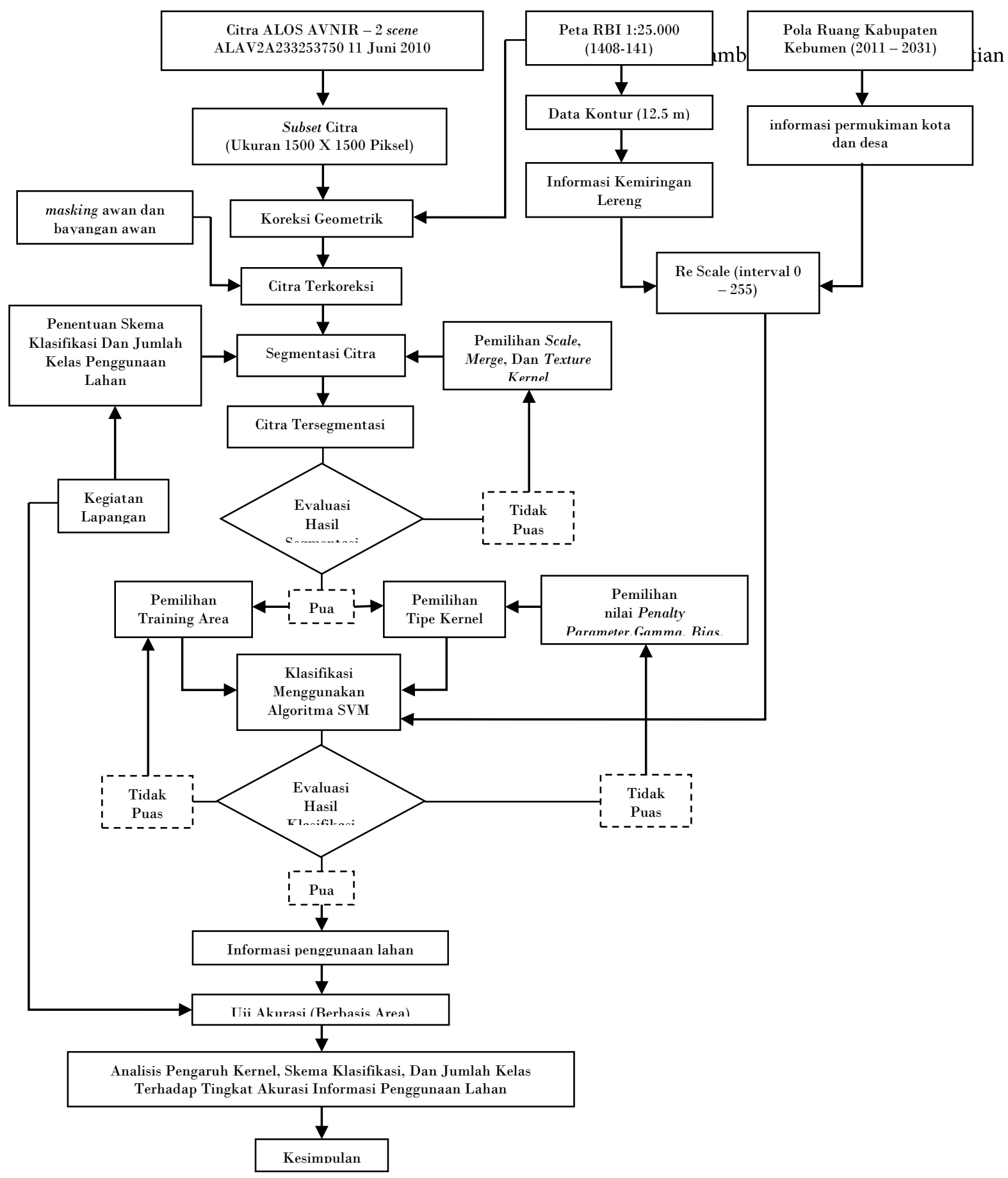

Gambar 2. Diagram Alir Penelitian

Tabel 3. Uji Akurasi dari Setiap Kernel Dengan Objek Kelas Penggunaan Lahan yang Berbeda

\begin{tabular}{|c|c|c|c|c|c|c|c|}
\hline \multirow[t]{2}{*}{ Jumlah Kelas } & \multirow[t]{2}{*}{ Kernel } & \multicolumn{4}{|c|}{ Parameter Kernel } & \multirow{2}{*}{$\begin{array}{c}\text { Overall } \\
\text { Accuracy }\end{array}$} & \multirow{2}{*}{$\begin{array}{c}\text { Kappa } \\
\text { Coefficient }\end{array}$} \\
\hline & & Penalty Parameter & Gamma & Bias & Degree & & \\
\hline \multirow[t]{7}{*}{4 kelas penggunaan lahan } & Linier & 0 & & & & $53.06 \%$ & 0.172 \\
\hline & Linier & 250 & & & & $81.34 \%$ & 0.7085 \\
\hline & Linier & 150 & & & & $83.34 \%$ & 0.7405 \\
\hline & Linier & 100 & & & & $85.49 \%$ & 0.7748 \\
\hline & Linier & 50 & & & & $87.27 \%$ & 0.8048 \\
\hline & $\mathrm{RBF}$ & 100 & 0.03 & & & $78.44 \%$ & 0.6712 \\
\hline & $\mathrm{RBF}$ & 100 & 1 & & & $79.07 \%$ & 0.6825 \\
\hline
\end{tabular}


Lanjutan Tabel 3.

Jumlah Kelas

Kernel

4 kelas penggunaan lahan $\mathrm{RBF}$

$\mathrm{RBF}$

$\mathrm{RBF}$

Sigmoid

Sigmoid

Sigmoid

Sigmoid

Sigmoid

Sigmoid

Polynomial

Polynomial

Polynomial

Polynomial

Polynomial

7 kelas penggunaan lahan

\section{Linier}

Linier

Linier

$\mathrm{RBF}$

$\mathrm{RBF}$

RBF

Sigmoid

Sigmoid

Sigmoid

Polynomial

Polynomial

Polynomial

10 kelas penggunaan

lahan

Linier

Linier

RBF

RBF

Sigmoid

Sigmoid

Polynomial

Polynomial

Polynomial

10 kelas penggunaan

Linier

Linier

$\mathrm{RBF}$

$\mathrm{RBF}$

Sigmoid

Sigmoid

Polynomial

Polynomial
Parameter Kernel

Penalty Parameter

100

100

200

100

100

250

100

100

250

100

100

100

100

100

0

100

250

100

100

50

100

100

100

100

100

250

75

150

250

100

100

250

100

100

100

150

250

100

100

100

100

250

100
Gamma Bias Degree

Overall Kappa

Accuracy Coefficient

$81.17 \% \quad 0.7139$

$\begin{array}{ccc}5 & 70.79 \% & 0.555 \\ 0.01 & 82.53 \% & 0.7324\end{array}$

$\begin{array}{llll}0.03 & 1 & 80.48 \% & 0.696\end{array}$

$\begin{array}{llll}0.03 & 0.5 & 78.40 \% & 0.6638\end{array}$

$\begin{array}{llll}0.01 & 0.5 & 77.74 \% & 0.6531\end{array}$

$\begin{array}{llll}0.1 & 0.1 & 83.12 \% & 0.7398\end{array}$

$\begin{array}{llll}0.01 & 0.1 & 77.33 \% & 0.6459\end{array}$

$\begin{array}{llll}0.01 & 0 & 80.15 \% & 0.6947\end{array}$

$\begin{array}{lllll}0.03 & 1 & 1 & 80.62 \% & 0.7013\end{array}$

$\begin{array}{lllll}0.01 & 1 & 1 & 85.22 \% & 0.7703\end{array}$

$\begin{array}{lllll}5 & 1 & 1 & 82.69 \% & 0.7314\end{array}$

$\begin{array}{lllll}1 & 1 & 1 & 85.22 \% & 0.7703\end{array}$

$\begin{array}{lllll}0.5 & 1 & 1 & 87.27 \% & 0.8048\end{array}$

$56.00 \% \quad 0.4021$

$78.98 \% \quad 0.7192$

$79.80 \% \quad 0.7293$

$75.14 \% \quad 0.6647$

$73.21 \% \quad 0.6494$

$68.82 \% \quad 0.5774$

$66.76 \% \quad 0.547$

$67.61 \% \quad 0.5598$

$\begin{array}{ccccc}0.03 & 1 & & 68.52 \% & 0.5718 \\ 0.03 & 0.5 & 1 & 73.82 \% & 0.646\end{array}$

$\begin{array}{ccccc}0.03 & 0.5 & 1 & 73.82 \% & 0.646 \\ 0.01 & 1 & 6 & 77.68 \% & 0.7038\end{array}$

$\begin{array}{ccccc}0.01 & 1 & 6 & 77.68 \% & 0.7038 \\ 1 & 1 & 1 & 79.80 \% & 0.7293\end{array}$

$\begin{array}{lll}1 & 7.80 \% & 0.7293 \\ & 71.84 \% & 0.6269\end{array}$

$73.34 \% \quad 0.6466$

$\begin{array}{lll}0.1 & 71.58 \% & 0.6244\end{array}$

$\begin{array}{lll}1 & 68.38 \% & 0.5838\end{array}$

$\begin{array}{llll}0.03 & 1 & 66.51 \% & 0.5552\end{array}$

$\begin{array}{llll}0.03 & 0.5 & 68.54 \% & 0.583\end{array}$

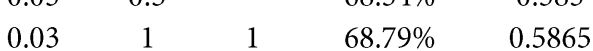

$\begin{array}{lllll}0.03 & 1 & 6 & 71.75 \% & 0.6257\end{array}$

$\begin{array}{lllll}1 & 1 & 1 & 72.25 \% & 0.6324\end{array}$

$74.99 \% \quad 0.6625$

$75.88 \% \quad 0.6746$

$77.57 \% \quad 0.6982$

$76.46 \% \quad 0.6838$

$73.95 \% \quad 0.6496$

$76.20 \% \quad 0.6782$

$72.42 \% \quad 0.6283$

$76.78 \% \quad 0.6883$

Sumber : Hasil Pengolahan

Tabel 4. Nilai Uji Akurasi Dari Jumlah Kelas Per OBIA Dengan Kernel Algoritma SVM

\begin{tabular}{ccccccccccc}
\hline & \multicolumn{3}{c}{ OBIA SVM LINIER } & \multicolumn{2}{c}{ OBIA SVM RBF } & \multicolumn{2}{c}{ OBIA SVM } & \multicolumn{2}{c}{ OBIA SVM SIGMOID } \\
Keterangan & & Overall & Kappa & Overall & Kappa & Overall & Kappa & Overall & Kappa \\
& & Accuracy & Coefficient & Accuracy & Coefficient & Accuracy & Coefficient & Accuracy & Coefficient \\
\hline Jumlah Kelas & 4 & $87.27 \%$ & 0.8048 & $82.53 \%$ & 0.7324 & $87.27 \%$ & 0.8048 & $83.12 \%$ & 0.7398 \\
Penggunaan Lahan & 7 & $79.80 \%$ & 0.7293 & $75.14 \%$ & 0.6647 & $79.80 \%$ & 0.7293 & $68.52 \%$ & 0.5718 \\
& 10 & $73.34 \%$ & 0.6466 & $71.58 \%$ & 0.6244 & $72.25 \%$ & 0.6324 & $68.54 \%$ & 0.583 \\
& $10+$ & $75.88 \%$ & 0.6746 & $77.57 \%$ & 0.6982 & $76.78 \%$ & 0.6883 & $76.20 \%$ & 0.6782 \\
\hline
\end{tabular}


Diagram Tingkat Akurasi dengan Jumlah Kelas yang Berbeda

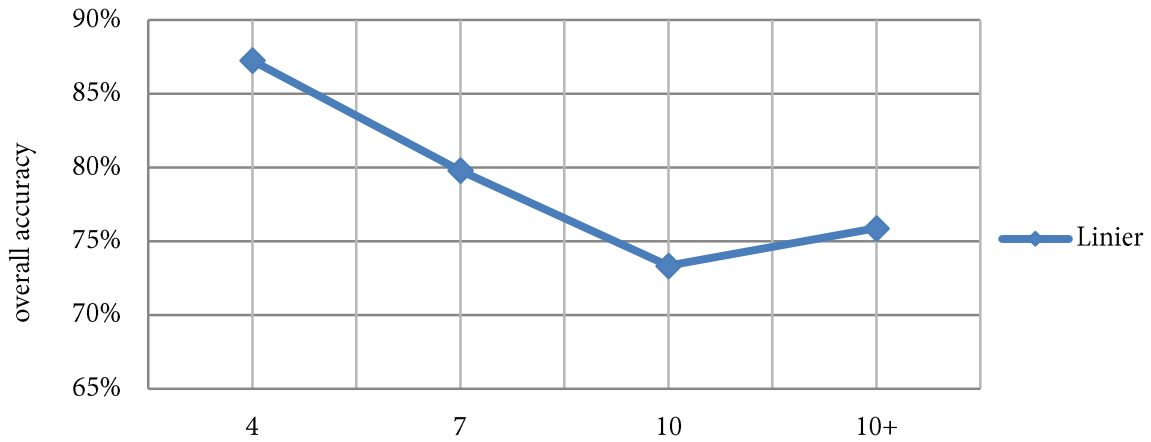

Diagram Tingkat Akurasi dengan Jumlah Kelas yang Berbeda

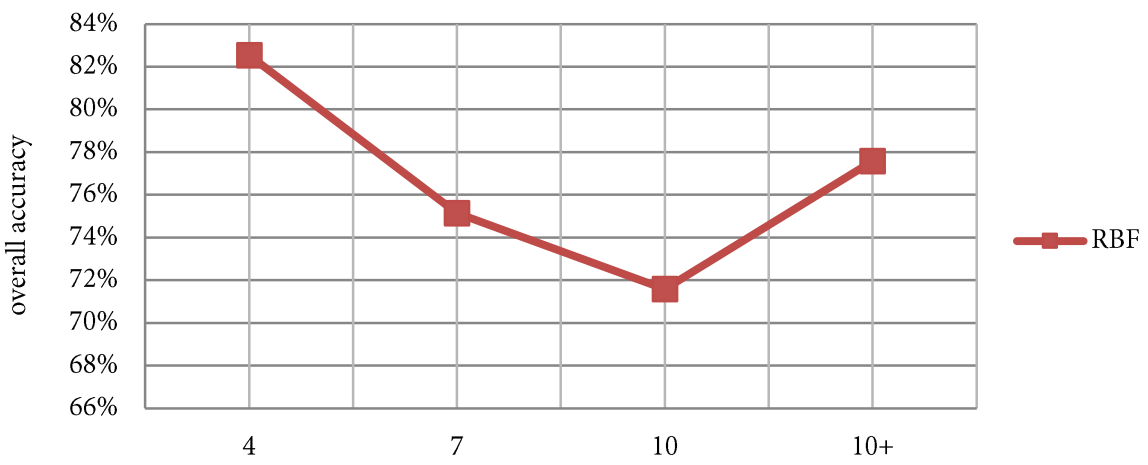

Diagram Tingkat Akurasi dengan Jumlah Kelas yang Berbeda

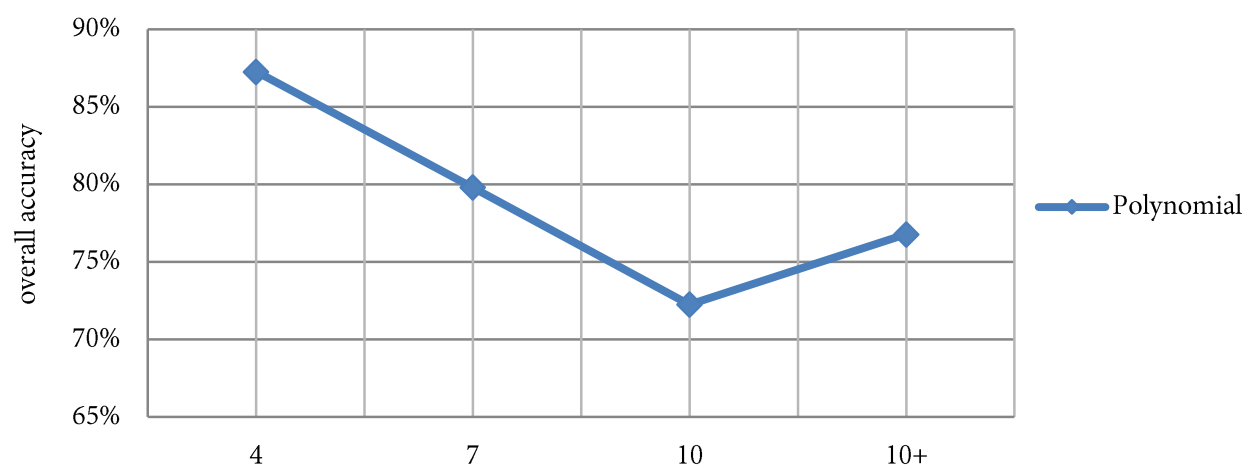

Diagram Tingkat Akurasi dengan Jumlah Kelas yang Berbeda

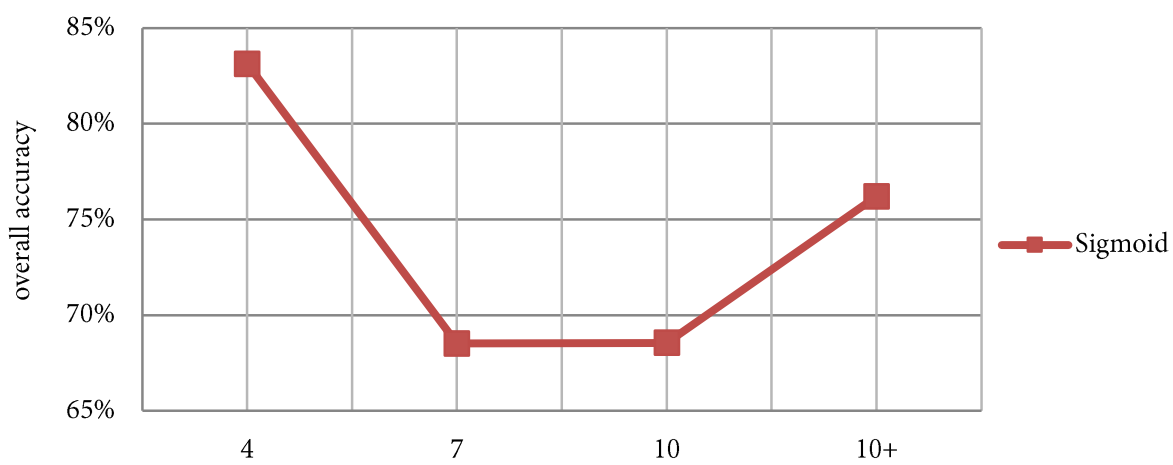

Gambar 4. Diagram Tingkat Akurasi Perkernel SVM dengan Jumlah Kelas yang Berbeda 
Dapat dilihat dari diagram untuk setiap kelas simulasi setiap kernel memiliki penurunan akurasi (Gambar 9). Hal ini di sebabkan oleh pemisahan data yang semakin kompleks akibat jumlah kelas yang meningkat. Namun hal ini bisa di perbaiki dengan menambahkan data bantu dalam memberikan informasi spesifik dari sebuah data misal : sawah tadah hujan memiliki kesesuaian lahan dengan lereng di atas $8 \%$, permukiman kota dapat di batasi oleh yuridis administratif, dll.

Dalam setiap simulasi setiap kernel memiliki tingkat akurasi yang berbeda - beda. Kernel linier memiliki hasil kepuasan yang baik di bandingkan dengan kernel lainnya jika di lihat dari tingkat akurasi yang di hasilkan. Akurasi setiap kernel dalam simulasi kelas yang sama dapat di tingkatkan dengan memperbaiki dan atau menambah jumlah sampel training area.

\section{Pengaruh Jumlah Kelas terhadap Akurasi Hasil Klasifikasi Berbasis Objek dengan Teknik Support Vector Machine}

Pengaruh jumlah kelas terhadap akurasi hasil klasifikasi berbasis objek dengan teknik support vector machine disajikan dalam Tabel 5, 6, 7, dan 8 .
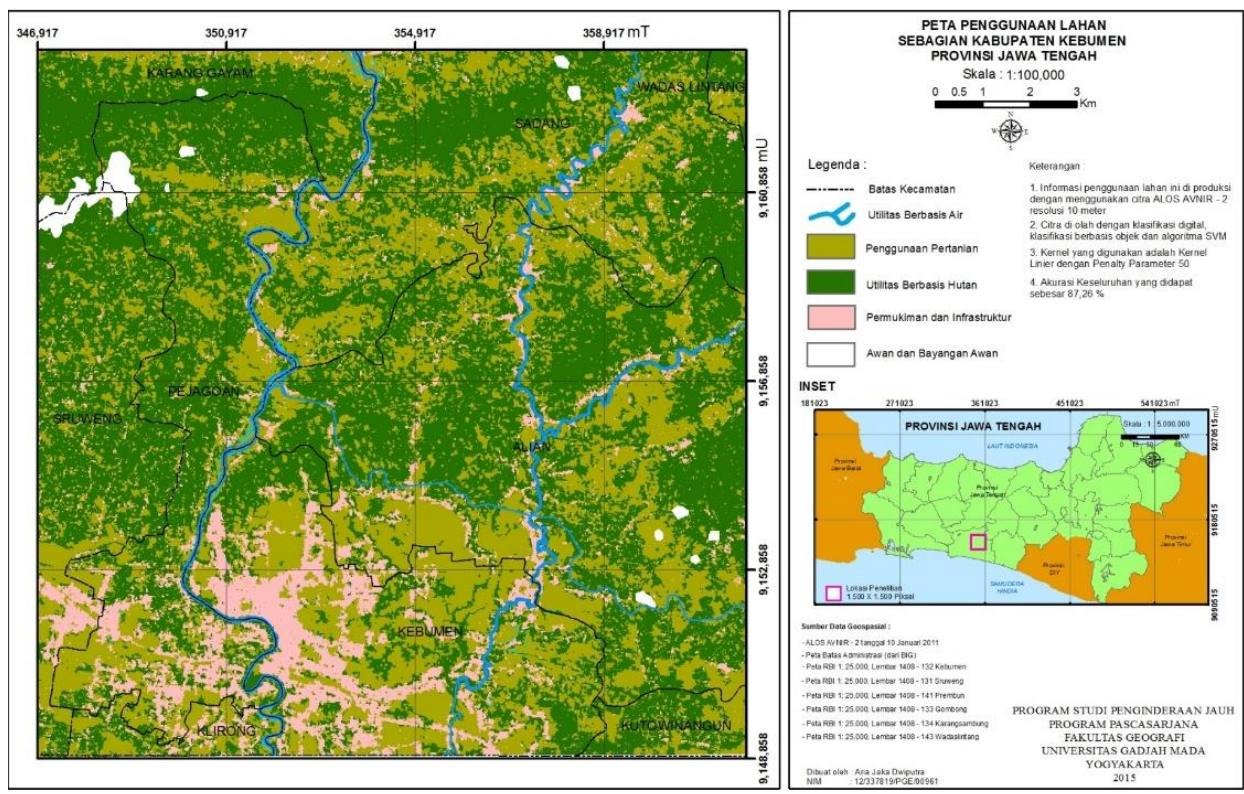

Gambar 5. Peta Penggunaan Lahan Sebagian Kabupaten Kebumen Provinsi Jawa Tengah (10 kelas PL) Menggunakan OBIA-SVM (Kernel Linier)
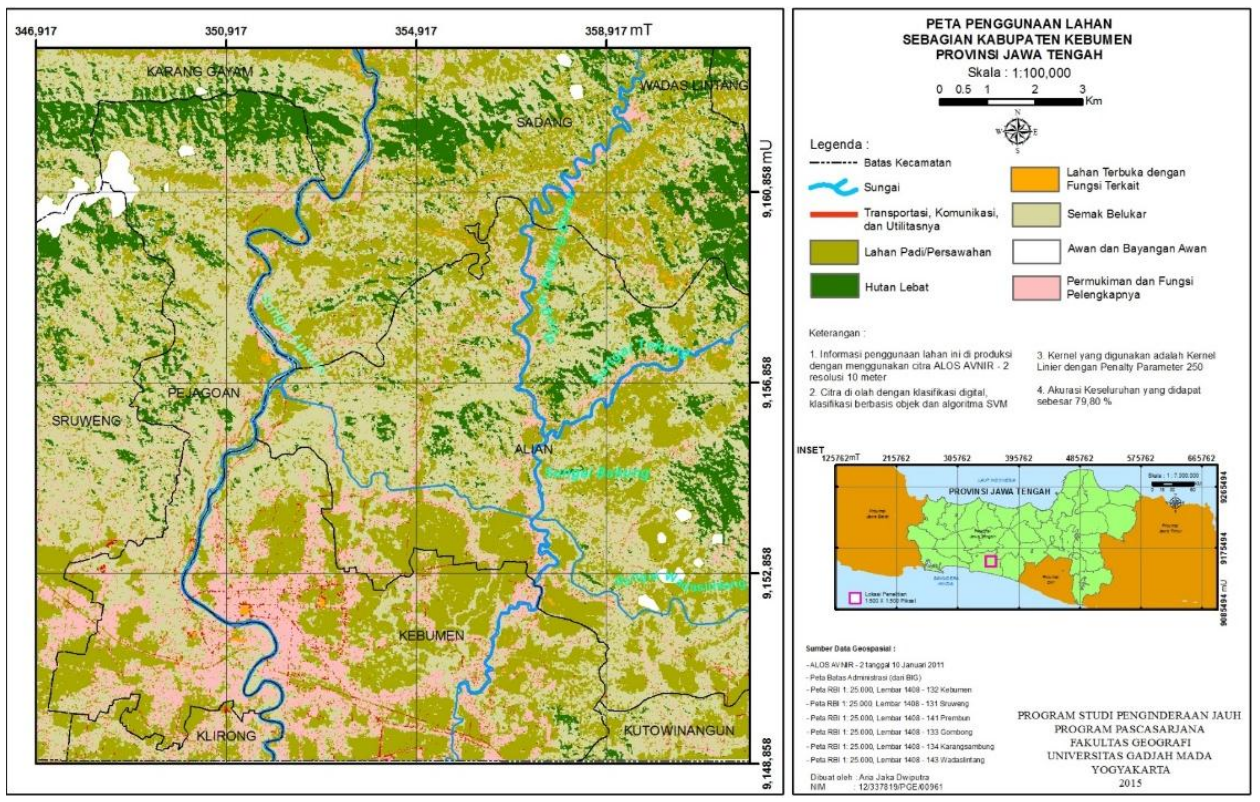

Gambar 6. Peta Penggunaan Lahan Sebagian Kabupaten Kebumen Provinsi Jawa Tengah (7 kelas PL) Menggunakan OBIA-SVM (Kernel Linier) 

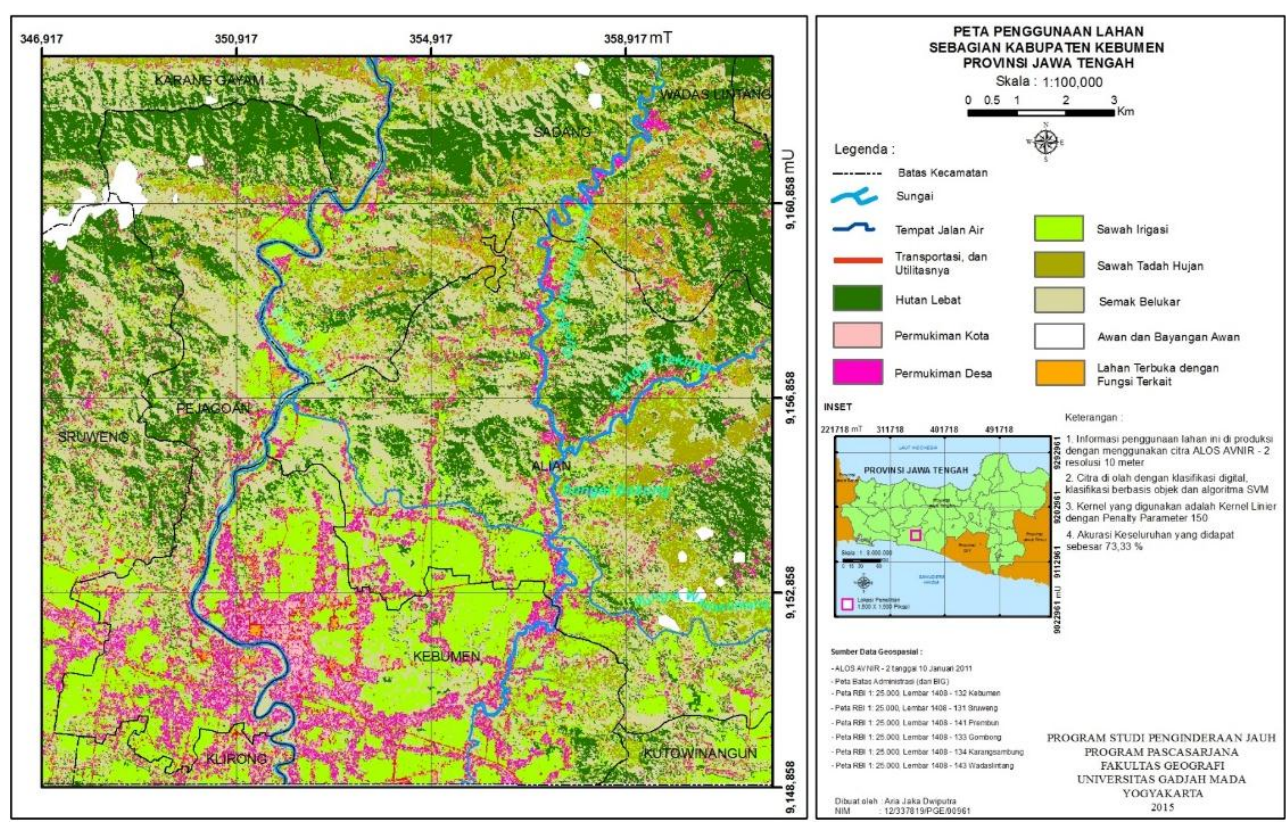

Gambar 7. Peta Penggunaan Lahan Sebagian Kabupaten Kebumen Provinsi Jawa Tengah (10 kelas PL) Menggunakan OBIA-SVM (Kernel Linier)
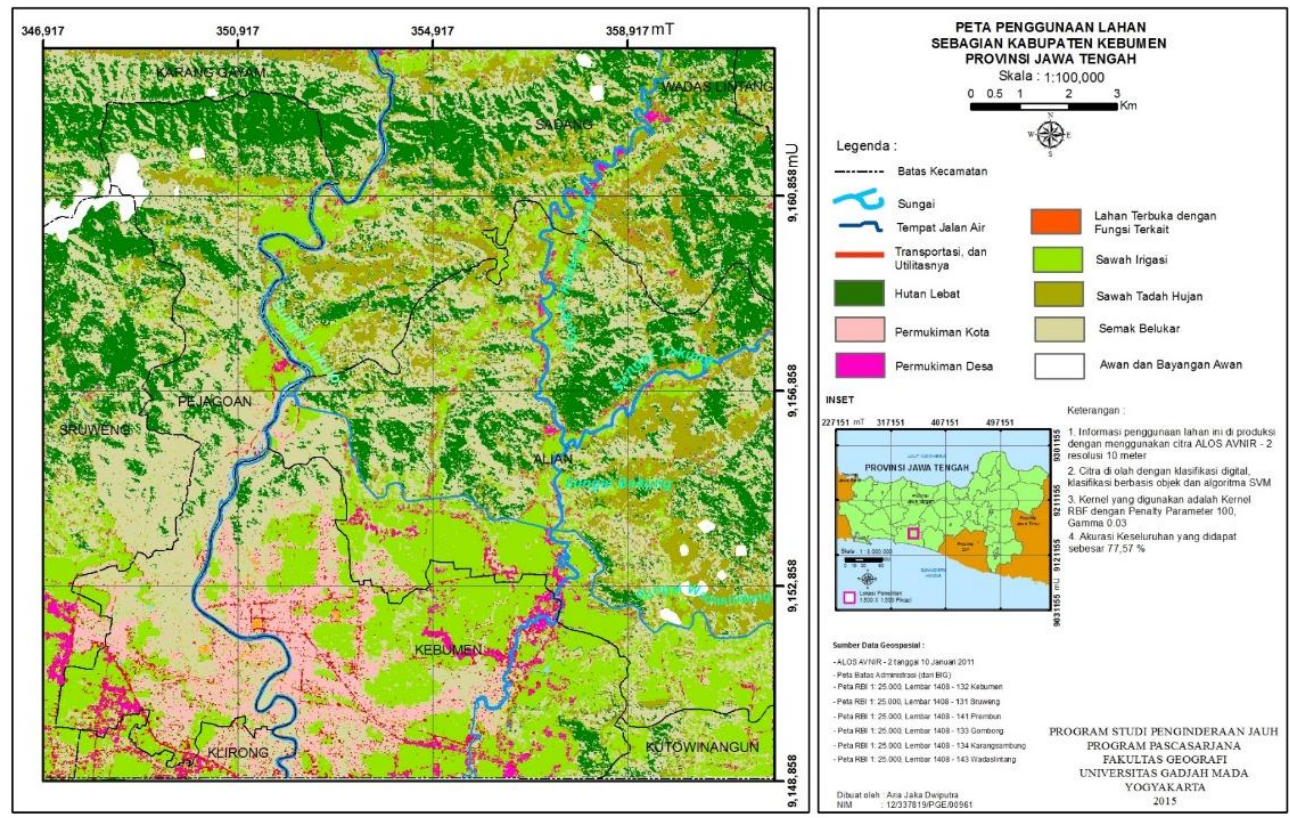

Gambar 8. Peta Penggunaan Lahan Sebagian Kabupaten Kebumen Provinsi Jawa Tengah (10 + kelas PL) Menggunakan OBIA-SVM (Kernel Radial Basis Function)

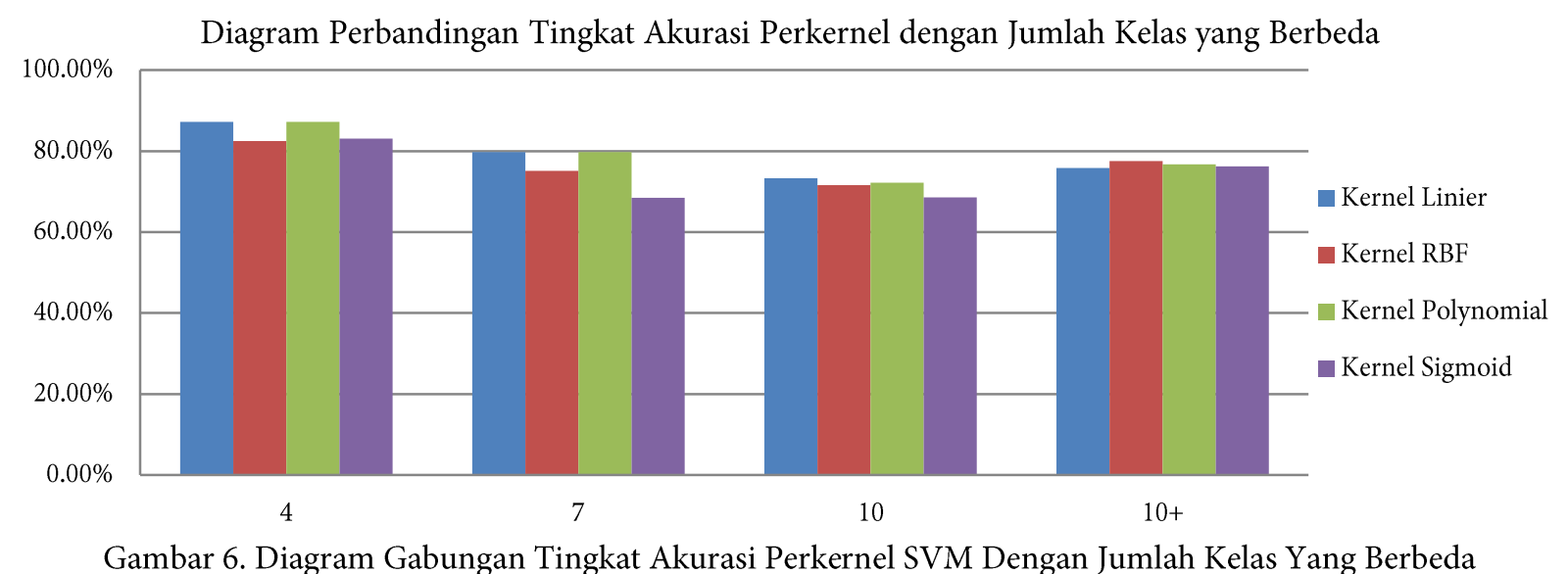

Gambar 6. Diagram Gabungan Tingkat Akurasi Perkernel SVM Dengan Jumlah Kelas Yang Berbeda 
Tabel 5. Nilai Uji Akurasi per Kelas Penggunaan Lahan Untuk 4 Kelas per Kernel SVM

\begin{tabular}{|c|c|c|c|c|c|c|c|c|}
\hline \multirow{3}{*}{ Keterangan } & \multicolumn{2}{|c|}{ Linier } & \multicolumn{2}{|c|}{ RBF } & \multicolumn{2}{|c|}{ Sigmoid } & \multicolumn{2}{|c|}{ Polynomial } \\
\hline & Producer & User's & Producer & User's & Producer & User's & Producer & User's \\
\hline & Accuracy & Accuracy & Accuracy & Accuracy & Accuracy & Accuracy & Accuracy & Accuracy \\
\hline Utilitas & 76.63 & 69.28 & 85.07 & 80.25 & 92.66 & 79.65 & 76.63 & 69.28 \\
\hline \multicolumn{9}{|l|}{ Berbasis Air } \\
\hline Utilitas & 88.3 & 86.02 & 81.52 & 83.08 & 85.89 & 86.11 & 88.3 & 86.02 \\
\hline \multicolumn{9}{|l|}{ Berbasis } \\
\hline \multicolumn{9}{|l|}{ Hutan } \\
\hline Penggunaan & 89.02 & 87.67 & 84.04 & 82.42 & 86.03 & 81.46 & 89.02 & 87.67 \\
\hline \multicolumn{9}{|l|}{ Pertanian } \\
\hline Permukiman & 83.66 & 91.75 & 80.19 & 82.44 & 71.31 & 83.57 & 83.66 & 91.75 \\
\hline \multicolumn{9}{|l|}{ Dan } \\
\hline \multicolumn{9}{|l|}{ Infrastruktur } \\
\hline Overall & $87 \%$ & 0.8048 & $83 \%$ & 0.7324 & $83 \%$ & 0.7398 & $87 \%$ & 0.8048 \\
\hline Accuracy & & & & & & & & \\
\hline
\end{tabular}

Tabel 6. Nilai Uji Akurasi per Kelas Penggunaan Lahan untuk 7 Kelas per Kernel SVM

\begin{tabular}{|c|c|c|c|c|c|c|c|c|}
\hline \multirow[b]{2}{*}{ Keterangan } & \multicolumn{2}{|c|}{ Linier } & \multicolumn{2}{|c|}{$\mathrm{Rbf}$} & \multicolumn{2}{|c|}{ Sigmoid } & \multicolumn{2}{|c|}{ Polynomial } \\
\hline & $\begin{array}{l}\text { Producer } \\
\text { Accuracy }\end{array}$ & $\begin{array}{c}\text { User's } \\
\text { Accuracy }\end{array}$ & $\begin{array}{l}\text { Producer } \\
\text { Accuracy }\end{array}$ & $\begin{array}{c}\text { User's } \\
\text { Accuracy }\end{array}$ & $\begin{array}{l}\text { Producer } \\
\text { Accuracy }\end{array}$ & $\begin{array}{c}\text { User's } \\
\text { Accuracy }\end{array}$ & $\begin{array}{l}\text { Producer } \\
\text { Accuracy }\end{array}$ & $\begin{array}{c}\text { User's } \\
\text { Accuracy }\end{array}$ \\
\hline Sungai & 83.83 & 84.22 & 87.28 & 82.92 & 92.71 & 77.4 & 83.83 & 84.22 \\
\hline Semak Belukar & 78.03 & 70.1 & 77.41 & 93.39 & 73.83 & 93.11 & 91.19 & 93.69 \\
\hline Hutan Lebat & 91.19 & 93.69 & 79.3 & 63.67 & 80.37 & 57.95 & 78.03 & 70.1 \\
\hline $\begin{array}{l}\text { Lahan } \\
\text { Padi/Persawahan }\end{array}$ & 80.39 & 80.04 & 78.91 & 75.33 & 72.26 & 66.84 & 80.39 & 80.04 \\
\hline $\begin{array}{l}\text { Permukiman } \\
\text { Dan Fungsi } \\
\text { Pelengkapnya }\end{array}$ & 74.9 & 92.32 & 62.04 & 92.56 & 45.19 & 82.27 & 74.9 & 92.32 \\
\hline $\begin{array}{l}\text { Transportasi, } \\
\text { Komunikasi Dan } \\
\text { Utilitasnya }\end{array}$ & 43.38 & 30.09 & 42.88 & 28.57 & 27.05 & 21.72 & 43.38 & 30.09 \\
\hline $\begin{array}{l}\text { Lahan Terbuka } \\
\text { Dengan Fungsi } \\
\text { Terkait }\end{array}$ & 66.99 & 50.58 & 69.04 & 51.3 & 47 & 68.29 & 66.99 & 50.58 \\
\hline Overall Accuracy & $80 \%$ & 0.7293 & $75 \%$ & 0.6647 & $69 \%$ & 0.5718 & $80 \%$ & 0.7293 \\
\hline
\end{tabular}

Sumber : Hasil Pengolahan

Tabel 7. Nilai Uji Akurasi per Kelas Penggunaan Lahan untuk 10 Kelas per Kernel SVM

\begin{tabular}{|c|c|c|c|c|c|c|c|c|}
\hline \multirow{3}{*}{ Keterangan } & \multicolumn{2}{|c|}{ Linier } & \multicolumn{2}{|c|}{$\mathrm{RBF}$} & \multicolumn{2}{|c|}{ Sigmoid } & \multicolumn{2}{|c|}{ Polynomial } \\
\hline & Producer & User's & Producer & User's & Producer & User's & Producer & User's \\
\hline & Accuracy & Accuracy & Accuracy & Accuracy & Accuracy & Accuracy & Accuracy & Accuracy \\
\hline Sungai & 84.69 & 39.5 & 84.41 & 39.05 & 86.06 & 36.51 & 87.84 & 38.5 \\
\hline Saluran & 44.48 & 58.19 & 43.51 & 54.92 & 39.92 & 39.26 & 42.51 & 58.31 \\
\hline \multicolumn{9}{|l|}{ Drainase/Irigasi } \\
\hline Hutan Lebat & 79.34 & 90.23 & 76.69 & 89.22 & 75.07 & 86.62 & 78.3 & 89.52 \\
\hline Semak Belukar & 68.14 & 56.37 & 71.01 & 55.92 & 73.42 & 52.75 & 69.17 & 57.16 \\
\hline Sawah Tadah & 67.05 & 69.24 & 65.6 & 68.78 & 52.11 & 64.83 & 65.12 & 69.36 \\
\hline \multicolumn{9}{|l|}{ Hujan } \\
\hline Sawah Irigasi & 75.29 & 67.74 & 70.37 & 64.57 & 68.09 & 66.56 & 73.49 & 64.85 \\
\hline Perumahan & 65.98 & 88.32 & 66.05 & 84.47 & 64.67 & 73.62 & 62.79 & 85.8 \\
\hline \multicolumn{9}{|l|}{ Kota } \\
\hline Permukiman & 69.71 & 48.28 & 58.8 & 45.44 & 27.95 & 25.71 & 62.91 & 43.37 \\
\hline \multicolumn{9}{|l|}{ Desa } \\
\hline Transportasi & 51.11 & 30.67 & 58.41 & 30.13 & 40.67 & 26.11 & 51.02 & 29.17 \\
\hline Dan Utilitasnya & & & & & & & & \\
\hline
\end{tabular}


Lanjutan Tabel 7.

\begin{tabular}{|c|c|c|c|c|c|c|c|c|}
\hline \multirow{3}{*}{ Keterangan } & \multicolumn{2}{|c|}{ Linier } & \multicolumn{2}{|c|}{$\mathrm{RBF}$} & \multicolumn{2}{|c|}{ Sigmoid } & \multicolumn{2}{|c|}{ Polynomial } \\
\hline & Producer & User's & Producer & User's & Producer & User's & Producer & User's \\
\hline & Accuracy & Accuracy & Accuracy & Accuracy & Accuracy & Accuracy & Accuracy & Accuracy \\
\hline Lahan & 51.24 & 72.74 & 52.69 & 68.66 & 42.91 & 59.84 & 50.72 & 70.74 \\
\hline \multicolumn{9}{|l|}{ Terbuka } \\
\hline \multicolumn{9}{|l|}{ Dengan } \\
\hline \multicolumn{9}{|l|}{ Fungsi } \\
\hline \multicolumn{9}{|l|}{ Terkait } \\
\hline Overall & $73 \%$ & 0.6466 & $72 \%$ & 0.6244 & $69 \%$ & 0.583 & $72 \%$ & 0.6324 \\
\hline Accuracy & & & & & & & & \\
\hline
\end{tabular}

Sumber : Hasil Pengolahan

Tabel 8. Nilai Uji Akurasi per Kelas Penggunaan Lahan untuk 10 Kelas (Menggunakan Data Bantu) per Kernel SVM

\begin{tabular}{|c|c|c|c|c|c|c|c|c|}
\hline \multirow{3}{*}{ Keterangan } & \multicolumn{2}{|c|}{ Linier } & \multicolumn{2}{|c|}{$\mathrm{RBF}$} & \multicolumn{2}{|c|}{ Sigmoid } & \multicolumn{2}{|c|}{ Polynomial } \\
\hline & Producer & User's & Producer & User's & Producer & User's & Producer & User's \\
\hline & Accuracy & Accuracy & Accuracy & Accuracy & Accuracy & Accuracy & Accuracy & Accuracy \\
\hline Sungai & 86.55 & 40.78 & 86.34 & 40.57 & 85.02 & 38.54 & 86.55 & 44 \\
\hline $\begin{array}{l}\text { Saluran } \\
\text { Drainase/Irigasi }\end{array}$ & 48.67 & 62.33 & 58.58 & 79.02 & 62.81 & 57.3 & 46.92 & 59.99 \\
\hline Hutan Lebat & 85.14 & 86.38 & 84.26 & 86.53 & 85.77 & 85.55 & 84.18 & 88.19 \\
\hline Semak Belukar & 68.94 & 58.59 & 69.23 & 58.67 & 67.82 & 59.15 & 73.94 & 60.24 \\
\hline $\begin{array}{l}\text { Sawah Tadah } \\
\text { Hujan }\end{array}$ & 60.34 & 67.57 & 77.05 & 70.5 & 73.13 & 68.68 & 62.63 & 65.94 \\
\hline Sawah Irigasi & 70.77 & 73.86 & 73.46 & 81.27 & 71.64 & 79.07 & 71.28 & 75.19 \\
\hline $\begin{array}{l}\text { Perumahan } \\
\text { Kota }\end{array}$ & 90.38 & 93.12 & 92.68 & 94.59 & 91.38 & 94.48 & 90.92 & 93.12 \\
\hline $\begin{array}{l}\text { Permukiman } \\
\text { Desa }\end{array}$ & 76.6 & 86.38 & 65.21 & 79.03 & 25.59 & 45.91 & 73.52 & 86.53 \\
\hline $\begin{array}{l}\text { Transportasi } \\
\text { Dan Utilitasnya }\end{array}$ & 23.92 & 17.25 & 16.41 & 21.29 & 14.18 & 15.2 & 34.22 & 22.33 \\
\hline Lahan Terbuka & & & & & & & & \\
\hline Dengan Fungsi & 46.68 & 88.65 & 50.88 & 93.66 & 46.37 & 94.3 & 50.26 & 88.08 \\
\hline Terkait & & & & & & & & \\
\hline $\begin{array}{l}\text { Overall } \\
\text { Accuracy }\end{array}$ & $76 \%$ & 0.6746 & $78 \%$ & 0.6982 & $76 \%$ & 0.6782 & $77 \%$ & 0.6883 \\
\hline
\end{tabular}

Sumber : Hasil Pengolahan

\section{KESIMPULAN}

1. Hasil ekstraksi informasi penggunaan lahan berbasis citra ALOS AVNIR -2 menggunakan klasifikasi berbasis objek dengan pendekatan SVM di rangkum sebagai berikut :

- Hasil ekstraksi informasi penggunaan lahan untuk jumlah kelas empat menggunakan klasifikasi berbasis objek dengan pendekatan support vector machine memiliki akurasi sebesar $87.2666 \%$ serta nilai koefesien kappa 0.8048 dan tipe kernel yang dipakai adalah kernel Linier;

- Hasil ekstraksi informasi penggunaan lahan untuk jumlah kelas tujuh menggunakan klasifikasi berbasis objek dengan pendekatan support vector machine memiliki akurasi sebesar $79.8021 \%$ serta nilai koefesien kappa 0.7293 dan tipe kernel yang dipakai adalah kernel Linier;
- Hasil ekstraksi informasi penggunaan lahan untuk jumlah kelas sepuluh menggunakan klasifikasi berbasis objek dengan pendekatan support vector machine memiliki akurasi sebesar $73.3377 \%$ serta nilai koefesien kappa 0.6466 dan tipe kernel yang dipakai adalah kernel Linier;

- Hasil ekstraksi informasi penggunaan lahan untuk jumlah kelas sepuluh menggunakan klasifikasi berbasis objek dengan pendekatan support vector machine dan ditambah dengan data bantu berupa informasi lereng dan informasi pola ruang memiliki akurasi sebesar $77.5705 \%$ serta nilai koefesien kappa 0.6982 dan tipe kernel yang dipakai adalah kernel Radial Basis Function;

2. Kernel linier dengan satu parameter menunjukkan akurasi tertinggi pada setiap jumlah kelas yang berbeda. Kernel linier menunjukkkan akurasi terendah ketika dipakai data bantu dalam proses 
klasifikasi. Berdasarkan hasil penelitian didapat bahwa dengan semakin banyaknya parameter yang dipakai dalam proses klasifikasi tidak berarti semakin akurat hasil klasifikasinya;

3. Setiap kernel memiliki pengaruh spesifik terhadap objek penggunaan lahan, dan untuk meningkatkan akurasi per objek penggunaan lahan dapat menggunakan data bantu.

\section{DAFTAR PUSTAKA}

Anderson, J.R., Hardy, E.E., Roach, J.T., and Witmer, R.E. (2001). A Land Use and Land Cover Classification System for Use With Remote Sensor Data, Washington: Geological Survey Professional Paper 967.

Blaschke, T. dan J. Strobl. (2001). What's wrong with pixels? Some recent developments interfacing remote sensing and GIS. GIS-Zeitschrift für Geoinformationssysteme. 14 (6), 12-17.

Blaschke, T. (2010). Object based image analysis for remote sensing. ISPRS Journal of Photogrammetry and Remote Sensing. 65, 2-16.

Danoedoro, P. (2006). Land-Use Information From The Satellite Imagery :Versatility and Contets for Local Physical Planning. Saarbrucken : Lambert Academic Publishing.

Foody, G. M. (2002). Status of Land Cover Accuracy Assesment. Remote Sensing of Environment. 80, 185- 201.
Gao, J. (2009). Digital Analysis of Remotely Sensed Imagery. New York. McGraw Hill

Hay, G. J., dan G. Castilla. (2006). Object-based Image Analysis : Strengths, Weakness, Opportunities and Threats (SWOT). The International Archives of The Photogrammetry, Remote Sensing and Spatial Informations Sciences. XXXVII (B7), 1159 - 1163.

Hay, G.J., dan G. Castilla. (2008). Geographic ObjectBased Image Analysis (GEOBIA) : A new name for a new discipline dalam Blaschke, $\mathrm{T}$, Lang, $\mathrm{S}$ dan Hay, G.J (Editor.) Object-Based Image Analysis : Spatial Concepts for Knowledge-Driven Remote Sensing Applications. New York : Springer, 3-27.

Huang, C., An Assessment of Support Vector Machines for Land Cover Classification. (2002). Int. J. Remote Sensing. 23(4), 725-749.

Lillesand, T.M., dan R,W. Kiefer. (2007). Penginderaan Jauh dan Interpretasi Citra. Yogyakarta: Gadjah Mada University Press.

Mather, P. (2004). Computer Processing of RemotelySensed Images: An Introductions. Chichester: John Wiley \& Sons Ltd.

Menno, JK. Dan Ferjan O. (2007). Kartografi : Visualisasi Data Geospasial Edisi Kedua. Yogyakarta: Gadjah Mada University Press.

Wong T. H., S. B. Mansor, M. R. Mispan, N. Ahmad, W. N. A. Sulaiman. (2004). Feature Extraction Based On Object Oriented Analysis. 